\title{
Remediation of Mudboil Discharges ifi the Tully Valley of Central New York
}

\section{What is a Mudboil?}

The Tully Valley mudboils are volcanolike cones of fine sand and silt that range from several inches to several feet high and from several inches to more than 30 feet in diameter. Active mudboils are dynamic ebb-and-flow features that can erupt and form a large cone in several days, then cease flowing, or they may discharge continuously for several years.

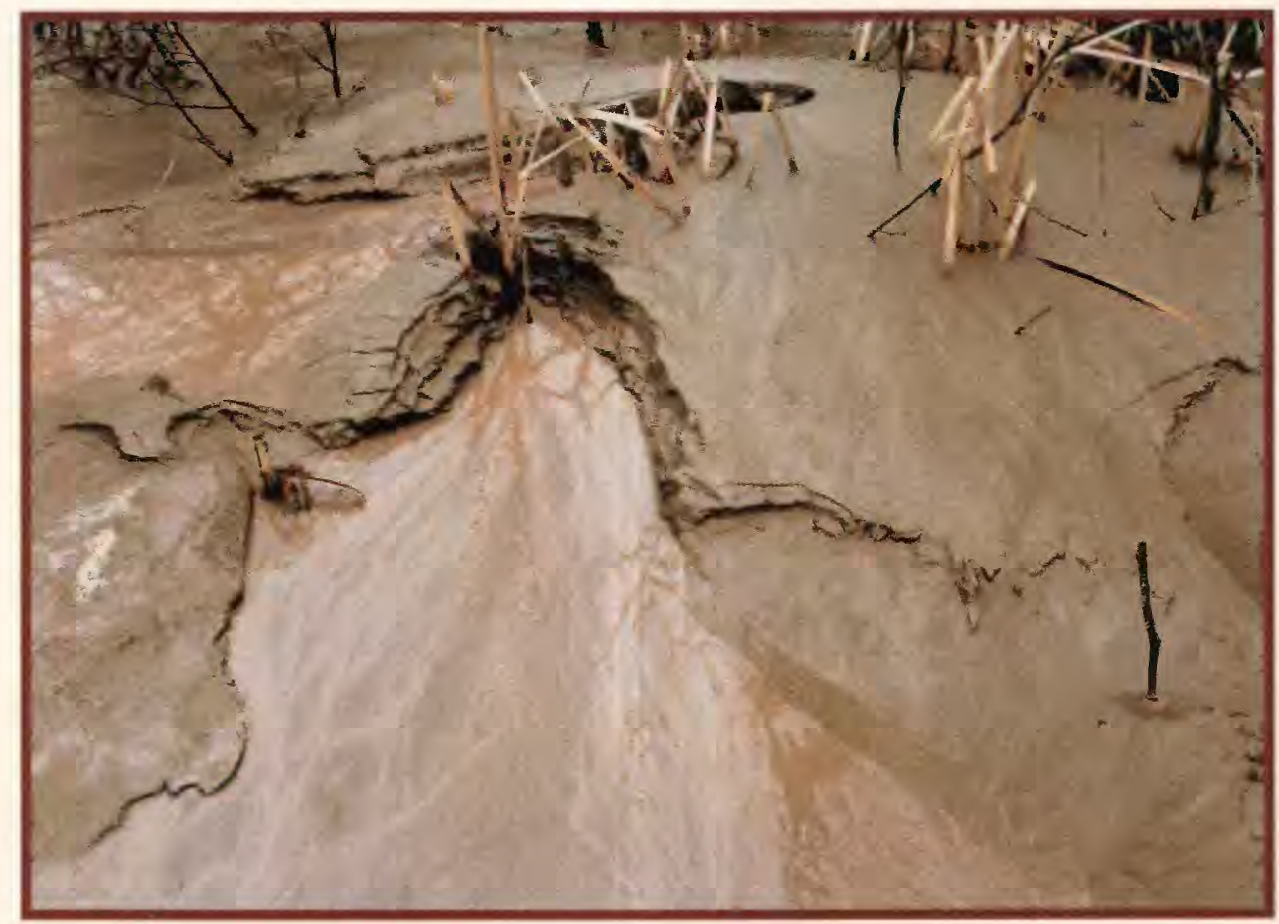

$\mathrm{M}$ udboils have been observed in the Tully Valley in Onondaga County, in central New York State, since the late 1890 's. Mudboils have continuously discharged sediment-laden (turbid) water into nearby Onondaga Creek, which flows to Onondaga Lake. The discharge of sediment causes gradual land-surface subsidence (fig. 1) that, in the past, necessitated rerouting a major petroleum pipeline and a buried telephone cable, and caused two road bridges to collapse. The water discharged from mudboils can be either fresh or brackish (salty).

Mudboil activity was first reported in the Syracuse, NY Post Standard, in a short article dated October 19, 1899:
"Tully Valley-A Miniature Volcano

Few people are aware of the existence of a volcano in this town. It is a small one, to be sure, but very interesting. In the 20rod gorge where the crossroad leads by the Tully Valley grist mill the hard highway bed has been rising foot after foot till the apex of a cone which has been booming has broken open and quicksand and water flow down the miniature mountain sides. It is an ever increasing cone obliterating wagon tracks as soon as crossed. The nearby bluff is slowly sinking. Probably the highway must sometime be changed on account of the sand and water volcano, unless it ceases its eruption."
This newspaper article accurately describes Tully Valley mudboils and presages the collapse of the Otisco Road bridge 92 years later in 1991. The article indicates that land subsidence occurred nearby, but gives no indication that Onondaga Creek was turbid; this was either an oversight by the reporter or was not a concern.

In 1991, the Onondaga Lake Management Conference identified the Tully Valley mudboils as the major source of turbidity being discharged into Onondaga Lake. Beginning in the fall of 1991, the Conference created the Mudboil Working Group (representing local, State, and Federal agencies) to 
Figure 1. (right) Mudboil/ Depression Area, known as the "MDA", as of November, 1994. View of land surface subsidence is toward the west from the MDA dam. (Location shown in fig. 3).

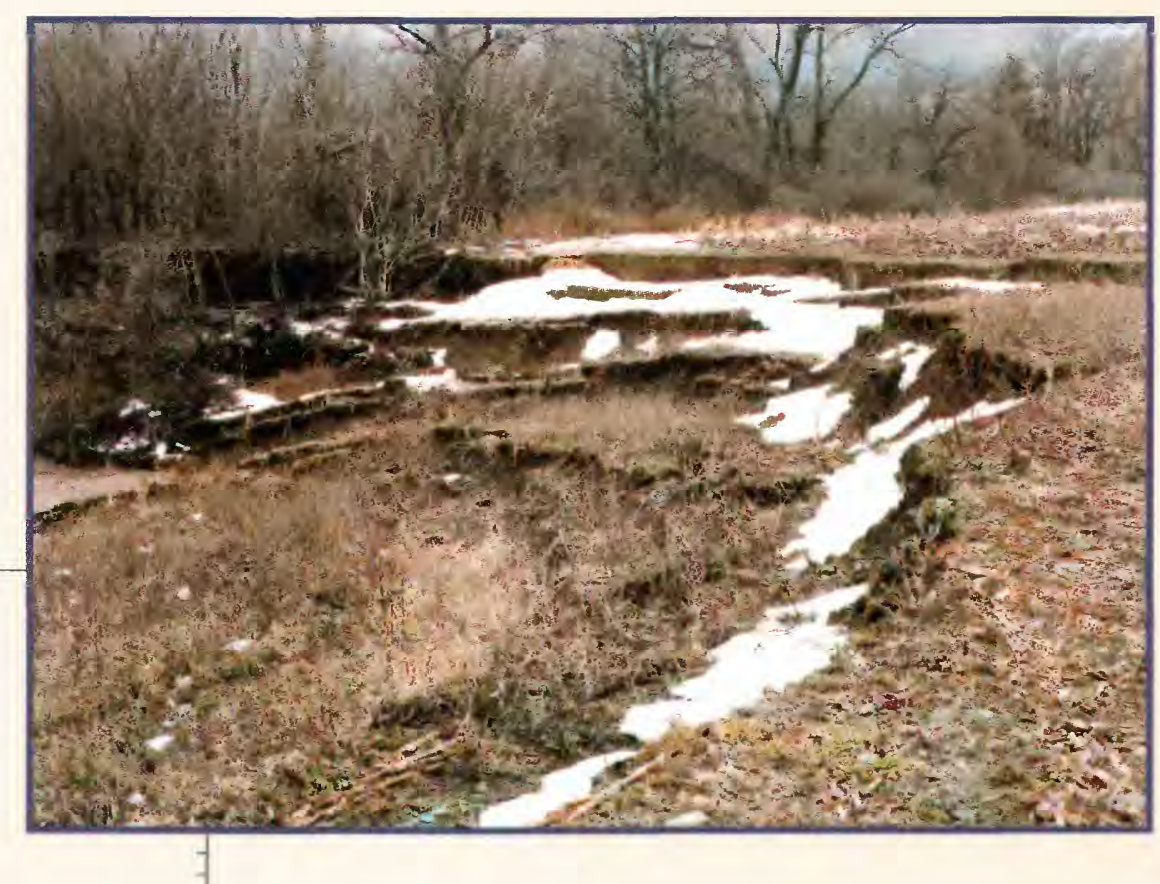

Figure 2. (left) Yearly average suspendedsediment load discharged to Onondaga Creek from the mudboil/depression area, water years 1992-96.

(1) develop a plan of study to identify the cause of mudboil activity, and (2) formulate ways to reduce or eliminate mudboil discharges, and thereby decrease or stop associated turbidity in Onondaga Creek, and nearby land subsidence. The U.S. Geological Survey in co-operation with researchers from the New York State Department of Environmental Conservation and Syracuse University, began the first comprehensive, long-term study of mudboil activity in the Tully Valley. The study plan was to: (1) define the mechanism and extent of mudboil development; (2) drill test wells to define the glacial stratigraphy (layering of glacial materials) and thereby delineate ground-water flowpaths within the valley, including drilling a deep test well to penetrate the salt beds below the mudboil area; (3) monitor the flow and sediment concentrations of mudboil discharges to calculate the amount of water and sediment discharged to Onondaga Creek; (4) identify remedial actions to reduce those discharges; and (5) monitor the results of those actions.

Flow from a mudboil is driven by artesian pressure that forces water and sediment upward from two sand and gravel aquifers through a 60 -foot-thick layer of dense silt and clay. The artesian pressure within the aquifer can lift water 20 feet above land surface within most of the valley floor and 30 feet above land surface near Onondaga Creek. The source of the artesian pressure is surface water entering the ground-water system along the valley walls - primarily at the southern end of the valley at the Tully Moraine and from the alluvial fans at the mouth of Rattlesnake Gulf and Rainbow Creeks.

The flow of water from the mudboils changes seasonally in response to changes in artesian pressure in the two aquifers. In the spring, when ground-water recharge is greatest, the mudboils in the main mudboil/depression area (MDA) (fig. 3, inset map) can discharge 400 gallons per minute or more. As recharge to aquifers declines during the summer, artesian pressure in the aquifers also declines, and flow from mudboils typically decreases to 200 gallons per minute or less. The rate of mudboil flow does not change in response to individual rainstorms but does respond to seasonal variations in precipitation.

Suspended-sediment discharge from the MDA to Onondaga Creek was measured between October 1991, and September, 1996. The daily average suspended sediment load for water years' 1992-96 are shown in fig. 2. Most of the suspended sediment is very fine clay and silt with a small fraction of very fine sand.

Chemical analyses of mudboil discharge in the MDA indicate that the source of water is either the confined freshwater aquifer or an underlying brackish-water (salty) aquifer (fig. 4). Chloride concentrations in the upper,

Water year - This is the 12-month period from October 1 through September 30. The water year ending on September 30, 1996 is the 1996 water year.

Purpose of the Onondaga Lake Management Conference:

"To prepare and implement a comprehensive Management Plan to define a cleanup strategy for Onondaga Lake, rehabilitate the Lake ecosystem, and restore beneficial uses of the Lake to the citizens of Onondaga County." 


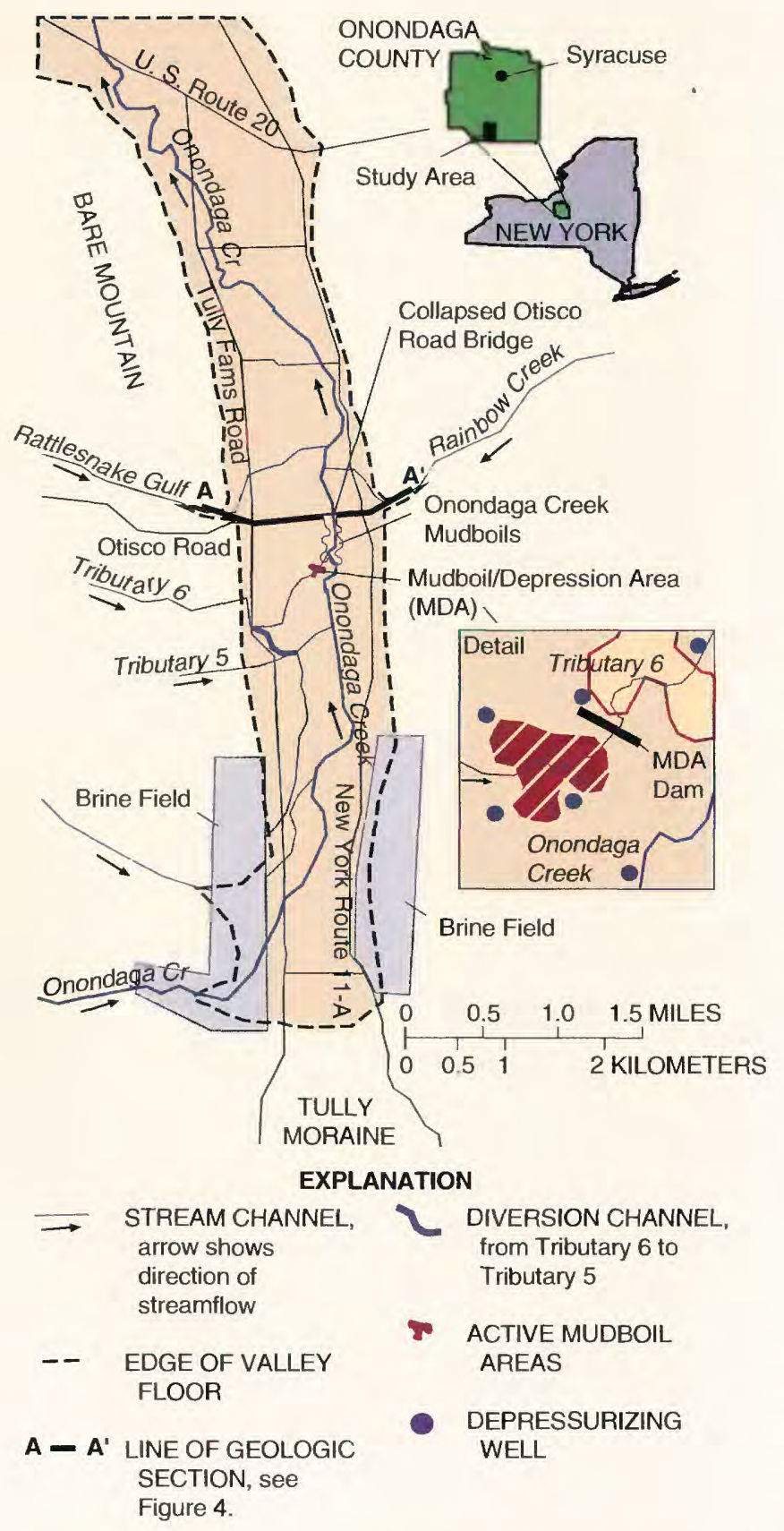

Figure 3. Principal geographic features of Tully Valley, N.Y., and locations of brine field, diversion channel, and mudboil areas. Inset map shows detail of MDA and locations of several depressurizing wells and outlet dam.

freshwater aquifer range from 37 to 430 milligrams per liter (mg/L) and from 2,000 to $7,100 \mathrm{mg} / \mathrm{L}$ in the lower, brackish-water aquifer. The difference in chloride concentration between these two aquifers is due partly to the greater density of the saltwater, which causes the brackish water to concentrate in the lower aquifer.

Remedial efforts near the Tully Valley mudboils include: (1) diverting flow from the tributary that feeds the MDA to an adjacent tributary; (2) installing depressurizing wells at several locations around the MDA and along Onondaga Creek to decrease the artesian pressure; and (3) constructing a dam and sediment-settling impoundment to detain mudboil sediment that would normally discharge to Onondaga Creek.

\section{Surface-Water Diversion}

Flow from the upper 0.7 square miles of the Tributary 6 drainage was diverted south to Tributary 5 (fig. 3 ), in June 1992. This diversion reduced total annual surface water inflow to the MDA by about two-thirds, which, in turn, reduced sediment loading to Onondaga Creek by half - from about 30 tons per day before diversion to about 15 tons per day thereafter.

\section{Aquifer Depressurizing Wells}

Depressurizing wells were installed near the collapsed Otisco Road bridge during the winter of 1992-93 in an effort to reduce artesian pressures in the upper aquifer and thereby slow nearby mudboil activity. The wells were drilled to the base of the freshwater aquifer, and 10-foot-long well screens were installed to allow artesian-pressured water to flow out of the well while holding the fine-grained sand and silt in place. These wells have a combined discharge of about 25 gallons per minute of sediment-free water and have modestly reduced artesian pressure in the freshwater aquifer by about 1 pound per square inch, or about 2.5 feet of hydraulic head. Nearby mudboil activity did not increase, and no new mudboils have developed since the wells were installed. Furthermore, the discharge of nearby mudboils has been sediment free, indicating possible stability in the area.

Eight additional wells were installed in the aquifers underlying the MDA and Onondaga Creek in the summer of 1996 to further reduce artesian pressure and slow mudboil activity. Total ground-water discharge from all wells averages about 350 gallons per minute. The chemical quality of water discharged from these wells varies with position around the MDA; most of the flows from depressurizing wells screened in the upper aquifer around and downgradient from the MDA are slightly brackish to salty, indicating that water from the lower aquifer is migrating upward into the base of the upper, freshwater aquifer. Water quality upgradient (south) of the MDA, is generally fresh. Discharge from individual wells range from less than 5 gallons per minute to more than 100

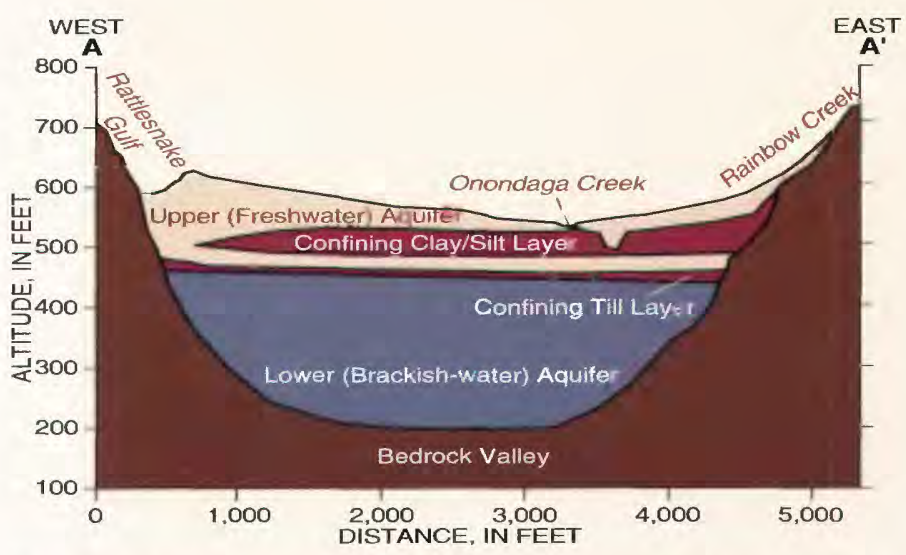

Figure 4. West-east geologic section between Rattlesnake Gulf and Rainbow Creek along Otisco Road, showing upper and lower glacial aquifers and confining clay layers. 
gallons per minute, depending on location and the aquifer material - flow from a coarse sand is much greater than flow from a fine-grained sand.

\section{Impoundment Dam}

A temporary dam was constructed at the outlet of the MDA (fig. 3, inset map) in July 1993 to reduce the average daily load of sediment discharging to Onondaga Creek. The impounded water covered several mudboils and allowed most of the silt and sand to settle out before flowing to Onondaga Creek. Also, the weight of water over active mudboils, and the additional weight of sediment settling on the mudboils decreased mudboil discharge. The impoundment, in conjunction with the depressurizing wells, has slowed mudboil activity in the MDA. and should slow land subsidence in this area as well.

The impoundment reduced the average daily load of sediment discharged from the MDA to Onondaga Creek, from 15 tons per day in 1992 to about 1.5 tons per day during water years 1993 and 1994, but by 1995, the entire impounded area was filled with sediment. Consequently, sediment loading to Onondaga Creek increased from 1.8 tons per day in water year 1995 to 2.8 tons per day in water year 1996 (fig. 2).

The dam was reconstructed to allow the outflow elevation to be raised in the summer of 1996 . The intent is to slowly increase the height of water over the remaining mudboils in the

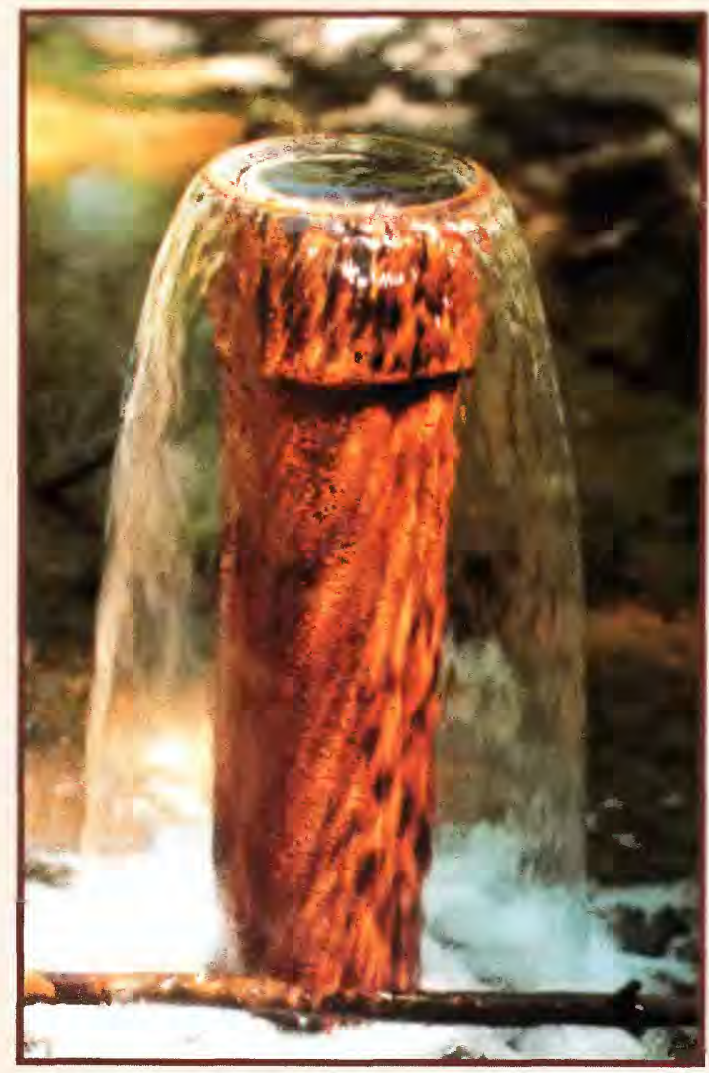

Figure 5. Depressurizing well flowing at a rate of more than 100 gallons per minute near the MDA.
MDA while the surrounding depressurizing wells are in operation. The increased amount of water and sediment over the active mudboils are expected to slow mudboil activity and cause the wells to discharge increased amounts of sedimentfree water to the Creek.

\section{Conclusions}

The Onondaga Lake Management Conference's primary goal is to restore the lake's ecological integrity. As one of seven major issues identified by the Conference, the Tully Valley mudboils "must be controlled to improve the water quality of the Creek and Lake, and their habitats." The Conference has funded the study of the mudboils within the mudboil/ depression area and along Onondaga Creek since 1991 and has funded these remediation projects which should, in time, slow mudboil activity.

Mudboils will persist in the Tully Valley as long as the two confined aquifers have artesian pressure that will 'push' water above land surface. The remediation projects are designed to (1) reduce artesian pressure that drives mudboil activity, and (2) decrease the discharge of sediment. These projects are expected to slow, but not stop, mudboil activity. As a result, turbidity in Onondaga Creek will decline, as will the rate of land subsidence in the Tully Valley. The results of this work will assist the Onondaga Lake Management Conference in improving the water quality of Onondaga Creek and Onondaga Lake.

\section{-William M. Kappel and Wendy S. McPherson--}

\section{Sources of Technical Information}

Kappel, W.M., Sherwood, D. A., and Johnston, W.H., Hydrogeology of the Tully Valley and characterization of mudboil activity, Onondaga County, New York: U.S. Geological Survey Water Resources Investigations Report 96-4043, 1996, $71 \mathrm{p}$.

Haley and Aldrich of New York, 1991, Report on mudboil occurrence in the Tully Valley, Onondaga County, New York: Rochester, N. Y., Haley and Aldrich of New York, prepared for Allied Signal Inc., 28 p.

Getchell, F.A., 1983, Subsidence in the Tully Valley, New York, unpublished thesis. Syracuse University, Syracuse, NY, $108 \mathrm{p}$.

Waller, R.M., Subsidence in New York related to groundwater discharge in Geological Survey Research 1977, U.S. Geological Survey Professional Paper 1050, p. 258.

\section{For more Information:}

Subdistrict Chief

U.S. Geological Survey

903 Hanshaw Rd

Ithaca, N.Y. 14850
This fact sheet and related information can be found on the World Wide Web at: http://ny.usgs.gov 